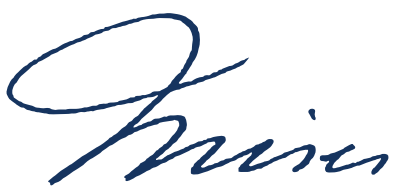

\title{
A Praxeological Theory of Interest Rates
}

\author{
Hendrik Hagedorn ${ }^{\mathrm{I}}$ (1) 0000-0002-6233-575X \\ University of Münster - Münster - North Rhine-Westphalia - Germany
}

\begin{abstract}
This paper starts with the observation that the pure time preference theory leads to conflicting views concerning the effect of changes in productivity on the rate of interest. Subsequently, it reviews the literature on the topic and concludes that the pure time preference theory cannot be considered praxeological. Then, it combines Hülsmann's theory of interest with the subjectivist capital theories of Lachmann and Kirzner, providing a praxeological theory that explains the rate of interest. The key to that theory is that cost reduction through fixed capital must always be understood in terms of the cost of labor that this capital replaces. Since labor is non-specific and its price also constitutes the production costs of fixed-capital goods to a certain extent, the use of fixed capital necessarily entails a business surplus somewhere in the economic system. Since this surplus cannot disappear, it qualifies as interest income. Its size is such that the interest rate corresponds to the marginal rate of substitution between labor and fixed capital, embodied in entrepreneurial actions.
\end{abstract}

Keywords: Interest Rate Theory, Praxeology, History of economic theory.

\footnotetext{
${ }^{\mathrm{I}}$ Dr. Hendrik Hagedorn earned his doctoral degree in economics under Prof. van Suntum at the university of Münster, Germany. He is also a graduate physicist, a former summer fellow at the Ludwig-von-Mises Institute in Auburn, and a former fellow at Graduate Center of the German Institute for Economic Research in Berlin. In 2013, he won the Don Lavoie Memorial Essay Competition. From 2016 to 2018, he was a college professor for economics at a business school in Berlin. Currently, he is a political advisor in the German parliament. His research interest include Austrian economics, praxeology, economic modeling, and epistemology. E-mail : h.hagedorn@protonmail.com.
} 


\section{Una Teoría praxiológica de los Tipos de Interés}

Resumen: Este trabajo comienza con la observación de que la teoría de la preferencia temporal pura conduce a opiniones contradictorias en cuanto al efecto de los cambios en la productividad sobre el tipo de interés. Posteriormente, examina partes de la literatura sobre intereses y concluye que la teoría de la preferencia temporal pura no es una teoría praxeológica. Entonces, el documento combina la teoría del interés de Hülsmann con la teoría del capital subjetivista de Lachmann y Kirzner y proporciona una teoría praxeológica que explica la tasa de interés. La clave de esa teoría es que la reducción de costes a través del uso de capital fijo siempre debe entenderse como relativa a los costes de la mano de obra que el capital reemplaza. Dado que la mano de obra no es especifica y el precio del trabajo, por lo tanto, también constituye los costes de producción de los bienes de capital fijo en cierta medida, el uso de capital fijo implica necesariamente un excedente empresarial en algún lugar del sistema económico. Dado que este excedente no puede desaparecer, se califica como ingreso por intereses. La magnitud de este ingreso es tal que el tipo de interés corresponde a la tasa marginal de sustitución entre el trabajo y el capital fijo, tal como se representa en las acciones empresariales.

Palabras clave: Teoría de los Tipos de Interés, Praxiologica, Historia de la economía.

\section{Uma teoria praxeológica dos juros}

Resumo: Esse artigo começa pela observação de que a teoria da preferência temporal pura leva a visões conflitantes a respeito do efeito das mudanças na produtividade sobre a taxa de juros. Posteriormente, examina partes da literatura sobre os juros e conclui que a teoria da preferência temporal pura não é uma teoria praxeológica. Então, combina a teoria do juro de Hülsmann com as teorias subjetivistas do capital de Lachmann e Kirzner, gerando uma teoria praxeológica que explica a taxa de juros. A chave dessa teoria é que a redução de custos através do capital fixo deve sempre ser entendida em termos do custo da mão de obra que esse capital substitui. Já que a mão de obra é não específica, e seu preço constitui, em certa medida, os custos de produção de bens de capital fixo, o uso do capital fixo implica necessariamente um excedente empresarial em algum lugar do sistema econômico. Já que o excedente não pode simplesmente desaparecer, qualifica-se como renda de juros. Seu tamanho é tal que a taxa de juros corresponde à taxa marginal de substituição entre mão de obra e capital fixo, tal como se representa nas ações empresariais.

Palavras-Chave: Teoria dos juros, Praxeologia, História da Economia. 


\section{Introduction}

In a manner of speaking, the theory of interest is the "Mecca" of economic theory. Every great economist has gone there, at least once in his lifetime; some of them whole-heartedly, others with the best intentions, and still others because they deemed it appropriate to do so. Nonetheless, the question as to what determines the rate of interest must be considered as hitherto unresolved. Ironically, the situation today is not much different from that of the days of Eugen von Böhm-Bawerk, who wrote that:

the present status of the theory of interest is characterized by a motley collection of the most varied opinions, of which none can achieve victory, and none is willing to admit defeat, and whose very numbers indicate to the impartial mind what a mass of error they must necessarily contain (BÖHM-BAWERK, 1959a, p. 4)

For example, the interest theory that most Austrian economists endorse is the so-called 'pure time-preference theory', which asserts that interest is the exclusive result of the time preference of human beings, i.e., their general preferring of things that are closer in time over things that are more distant in time (MISES, [1949] 2008, p. 521; ROTHBARD, [1962] 2009, p. 400; SOTO, 2009, p. 284). However, this theory clashes with many other stances. Neoclassical economists, for instance, see the rate of interest as simultaneously determined by (and equal to) the marginal productivity of capital and the time preference of a representative agent. For Keynesians, in contrast, it is the result of liquidity preference.

Even within the Austrian School, we observe conflicting views. Some Austrian scholars challenge the pure time-preference theory altogether, stating that it is not even a praxeological theory (MURPHY, 2001; HÜLSMANN, 2002, p.97; REISMAN, [1990] 1998, p.797; BRAUN, 2014). In contrast, Kirzner ([1993] 2011, p. 125) defends the theory but holds that it addresses a question different from that of interest rate determination. It is precisely in the question of what determines the size of the rate of interest that resides the greatest disagreement among the adherents of the pure time-preference theory. Ingo Pellengahr, who devoted most of his research to reviewing this literature, describes the situation as follows:

Whereas Fetter predicts that [a rise in physical productivity] will lower the rate of interest, Rothbard asserts that [it] will not affect the rate of interest at all. Kirzner does not exclude that it will affect the rate of interest, whereas Garrison (adducing to Fisher's reason, not Fetter's) contends that it might actually lower that rate. (PELLENGAHR, 1996, p. 63 [emphasis in the original] $)^{1}$

Given Böhm's opening remark, this calls for some elaboration, and we shall start with a definition and some general observations.

Interest is defined as the part of the business surplus that remains after all costs have been accounted for and that cannot be competed away through entrepreneurial effort, not

\footnotetext{
${ }^{1}$ The sources that he refers to in this passage are Fetter (1914, p. 247), Rothbard ([1962] 2009, p.424), Kirzner ([1993] 2011,
} p.119), and Garrison (1979, p.221) comic modeling, and epistemology. 
even in theory (MISES, [1949] 2008, p.532; KIRZNER, [1993] 2011, p.100; HÜLSMANN, 2002, p. 77). It is the income stream that accrues to capitalists through the market process, regularly and steadily, and in addition to what they obtain as risk or innovation premium (BÖHMBAWERK, 1959a, p .6). Any theory of interest thus argues and actually builds on the fact that the total amount of money spent on the products of businesses is generally and systematically higher than the total amount spent by businesses on factors of production. However, this is generally true, since business surpluses are regularly distributed to households, who - just as workers - eventually spend those means. There is, hence, a systematic spread between the total proceeds earned from the selling of products and the total expenditure paid on factors of production (REISMAN, [1990] 1998) ${ }^{2}$. The part of this spread that can or could be dissolved in the competition process is called entrepreneurial profit. The remainder is interest ${ }^{3}$. Of course, in reality, a spread between revenue and costs is the money a businessman makes. Whether this money is interest or entrepreneurial: profit can empirically not be distinguished. The two concepts can only be separated on theoretical grounds.

From these considerations, two things follow. First, that from a causal-realist perspective, interest must be conceived as a nominal and not a real phenomenon, which Murphy has already argued (2003, p. 127). In fact, there are only two ways how real interest can be conceptualized, and both are artificial. If, in line with Fisher's equation, real interest is understood as nominal interest after controlling for changes in the price level, then it is clearly only a secondary consideration, one that requires the computation of a price index and statistical knowledge about the economic system as a who ${ }^{4}$. However, a causal-realist approach should treat capitalist income and price relations in their own right. Alternatively, if real interest is conceptualized as an exchange rate between two types of goods (or baskets of goods), one deliberately separates theory and phenomenon, since such an exchange rate is precisely not how interest occurs. Instead of addressing the problem directly, one introduces an entirely inaccurate analogy that has the inconvenient side effect that the real rate of interest is not even uniquely defined once the number of considered goods is elevated above one (MURPHY, 2003, p.130) and that the nominal rate cannot be determined, since money is entirely abstracted in such models (MURPHY, 2003, p.138). The phenomenon to be explained is thus nominal, albeit real factors are constitutive of it ${ }^{5}$.

\footnotetext{
${ }^{2}$ Kalecki (1935, p. 45) and Robinson (1956, p. 43; p. 75; p. 255) also had previously made this observation. As a corollary, it follows that interest cannot become negative, but it does not follow that interest is always positive, since all surpluses could be pure entrepreneurial profit. As a side note, it also follows that the economy-wide occurrence of interest neither leads to a growth imperative nor to exponential accumulation of debt and a consequential system collapse as is frequently voiced in non-academic circles (WOODS JR., 2013).

${ }^{3}$ Böhm-Bawerk and Mises refer to this form of interest as "originary interest," thus emphasizing that interest on loans as well as rents derive from the interest that arises as a spread between business revenues and costs. However, we will avoid the term for reasons to be discussed in Section 3.

${ }^{4}$ On the problems measuring the price level and the arbitrariness involved, see Reisman ([1990] 1998, p. 674) and Mises (1954, p.187).

${ }^{5}$ I do not contend that the Austrian literature is generally guilty of treating interest as a real phenomenon, but the neoclassical literature makes this mistake.
} 
Second, since interest is not an equilibrium phenomenon, but occurs as part of business profits, it need not and actually should not be described through equilibrium constructions. In fact, to disentangle interest from entrepreneurial profit by appealing to the evenly rotating economy is auxiliary at best. The essence of the matter lies in the actual economic process. The argument necessary to explain interest satisfactorily is thus not one that describes a scenario in which entrepreneurial profits are absent, but one that shows how the economic process is constrained in a way that certain price spreads do not disappear, being preserved somewhere in the system. This notwithstanding, Gloria-Palermo (1999) reminds us that large parts of the Austrian theory are not formulated in this way, but instead in an equilibrium-like fashion. She explains this by pointing to the progressive neglect that Menger's (process-oriented) ideas underwent after the turn of the century and that much of the Austrian literature was developed before Mises formulated the idea of praxeology and Hayek introduced the theme of dispersed information. One of those theories that were coined and codified during that time was the theory of interest. It may also be for this reason that until today no praxeological theory of interest rates exists. Yet, to deliver such an argument is the purpose of this essay.

The critical question, however, is whether praxeology is actually capable of accounting for complex phenomena. Clearly, the analysis of one action alone cannot explain the occurrence of an economy-wide phenomenon like interest. Indeed, the transition from simple praxeology to praxeological process analysis is far from obvious: it can only be accomplished by extending the formal analysis characteristic of praxeology to the interplay of human actions. So, to describe the phenomenon of recurring interest, the spread between revenues and costs is traced through and along with the different entrepreneurial plans in which it arises, while only the formal implications of these actions are considered. This approach, pioneered by Hülsmann (2002) and discussed in Section 3, will be the basis of the theory presented in Section 4. Before this, however, we will look into the historical development of Austrian interest theory, particularly addressing how far the relevant theories qualify as praxeological. However, this historical treatment is not comprehensive. We refer the reader to the dissertations of Ingo Pellengahr (1996) and Robert Murphy (2003), as well as the literature referenced therein for a more detailed survey and critique. Reisman ([1990] 1998, p. 792) and Hülsmann (2002, p.78) provide further criticism of the pure time preference theory.

\section{A brief overview over Austrian interest theory}

\subsection{Eugen von Böhm-Bawerk - a disciple of Carl Menger?}

The pivotal work in interest theory is that of Eugen von Böhm-Bawerk, who reviewed and conclusively criticized the entire interest literature before him and strongly influenced the entire interest literature after him. By the time of his writing, marginalist reasoning had become the dominant paradigm in economics but mainly applied to problems without a time dimension. Böhm-Bawerk, however, applied the marginalist toolkit to an intertemporal problem and his theory of interest became the point of departure for both Austrian and neoclassical economists of the twentieth century. 
According to Böhm-Bawerk (1959b, p. 259), all forms of interest can be traced back to the fundamental principle that present consumer goods are generally more valuable to individuals than future consumer goods. This higher valuation of present goods is based on, first, their relative scarcity (p. 265); second, the subjective discount that people place on future utility (p. 268); and third, the productivity gains that can be reaped through the use of more roundabout and time-consuming modes of production, which, in turn, require labor and thus means of subsistence in the form of present consumer goods as input, so not using present goods is equivalent to a loss in output (p. 280). Following the laws of marginalism, which BöhmBawerk rigorously applies (p. 286), such a higher valuation leads to a price difference between present and future goods to the advantage of the former. According to Böhm-Bawerk, what turns these considerations into a theory of interest is that goods of remoter orders "though physically present, are in their economic nature future goods" (p. 299), in the sense that their market value derives from the consumer goods into which they will eventually be converted. Similarly, for durable goods and land, their remoter renditions of service are also future goods (p. 325). The prices of factors of production are thus systematically lower than the prices of consumer goods, raising the capitalist's income ${ }^{6}$.This disagio, which receives a definite rate through the interplay of the three causes (p. 283), and a definite size through the number of time periods separating each good from the consumer stage (p. 288), perfectly determines the prices of goods at each stage of production as well as the prices of durable goods and land. Given those prices, the subsistence fund, and the size of the labor force, the rate of interest coincides with the marginal value productivity of the greatest possible extension of the time period of production under the condition of market clearing in the subsistence market, in which the entire workforce can be sustained during the average time period of production (p. 355). With the assumption of decreasing returns to capital accumulation, the rate of interest will thus "rise in inverse ratio to the subsistence fund, in direct ratio to the working population which that fund must support, and in direct ratio to the degree of productivity that marks continued prolongation of the production period" (p.365).

In Böhm-Bawerk's approach, the appraisement of goods is thus passed along through the structure of production with a discount for each time period. Schum-peter (1954, p. 931) points out that, historically, this aspect was "perhaps the most important of all" in BöhmBawerk's theory. Contrary to that, for example, Herbener asserts (2011, p. 17) that Carl Menger, and not Böhm-Bawerk, introduced the discounting method into Austrian economics. So, discounting is commonly regarded as an original part of the Austrian paradigm. However, this view is questionable, since Böhm-Bawerk uses the concept in a highly formalistic manner, and his notion of the "future" good is largely metaphorical. In a way, he even turns Menger's theory upside down by treating capital goods as future goods. For Menger, who assumes the perspective of the acting entrepreneur, the products to be produced are future goods, while

\footnotetext{
${ }^{6}$ For Böhm-Bawerk, labor is also generally priced below the future price of the finished product because the majority of workers are in such great need of present goods that they cannot afford to wait until the products of roundabout modes of production are available. Therefore, they will offer their work at prices that correspond to the output of capital-less production (p. 308).
} 
goods of higher order are present goods. Indeed, Menger and Böhm-Bawerk would have agreed that goods to be produced must have a higher market value than the corresponding factors of production. For Menger, however, the price relation between them cannot be meaningfully approached by a discounted mathematical series. The main themes in Menger's work, which qualify him as the founding father of the Austrian School, are uncertainty, constant change, and the economizing behavior of man. Menger ([1976] 2007, p.199) emphasizes that the marginal pairs of subjective valuations only define a possible range within which prices will fall. The determination of an equilibrium situation is explicitly left open, since Menger's interest lies in the essential mechanism of price determination and the causes governing the evolution of economic processes (GLORIA-PALERMO, 1999). In contrast, Böhm-Bawerk is explicitly interested in the computation of equilibrium values, thus breaking with Menger's subjectivism on multiple levels. In fact, his approach is utterly negligent of the entrepreneur and the economic process. Like in the case of Walrasian tatönnement, only the end result of price formation is considered, while the process of price determination is left aside. The origination of value is relegated to the consumer level, and the value that entrepreneurs place on the goods they deal with does not appear in the theory. When establishing the equilibrium value of the rate of interest, Böhm-Bawerk (1959b, p. 355) even uses a proof by contradiction and thus demonstrates that the path towards equilibrium is not part of his theory ${ }^{8}$. Moreover, he reduces the capital structure to one objective figure, namely the average time period of production. This highly under complex notion of a capital structure, which has later found a famous rendition in the Hayekian triangle, bears the problem that goods are exclusively categorized according to their distance from the consumer stage and not according to their role in the subjective estimates of entrepreneurs ${ }^{9}$. The entire approach aims at objectivation, even if Böhm-Bawerk never conceived of the roundaboutness of production or the length of a production period in a literal sense, but metaphorically and with a host of qualifications (BÖHM-BAWERK, 1959c).

After all, Böhm-Bawerk's vision of marginalism is entirely different from Menger's. Böhm-Bawerk embraces the mathematical marginalism of Jevons and Walras and thus a form of marginalism that Menger explicitly refused, a form that Gloria Palermo calls static subjectivism as opposed to Menger's dynamic subjectivism. Given the clash of these competing paradigms, it is not surprising that Menger criticized Böhm-Bawerk's theory as the "greatest error ever committed" (SCHUMPETER, 1954, p. 847) ${ }^{10}$. And indeed, in the light of the above,

\footnotetext{
${ }^{7}$ He states that the sale of goods of higher order has a certain similarity to discounting (MENGER, [1871] 1950, p.158). In the German original (MENGER, 1871, p. 152), the word discounting appears as "eskomptieren", which actually means "to make an allowance" or "to make a price deduction". Only under very particular circumstances can it mean "to discount to present value".

${ }^{8}$ See Blaug (2003) for a review of how such non-constructive approaches have ultimately misled the entire economics profession.

${ }^{9}$ See in particular the correspondence between Menger and Walras as collected by Antonelli (1953). An English translation is available in (GLORIA-PALERMO, 2013).

${ }^{10} \mathrm{~A}$ commonly held explanation for their dispute is that it was centered around the productivity element in Böhm-Bawerk's theory. This is, however, not plausible since Menger's theory does contain an element of productivity, too, as Pellengahr (1996, p.12) points out (MENGER, [1871] 1950, p. 152).
} 
Böhm-Bawerk's interest theory cannot be considered as truly "Austrian". What rehabilitates Böhm-Bawerk's interest theory vis-a-vis the Mengerian approach is that it was never even conceptualized as a praxeological theory. From the outset, it was a psychological and marginalist theory (BÖHM-BAWERK, 1959b, p.381). Because of that, it can be considered in its own right and shall serve, without further criticism, as a point of reference for the following sections.

\subsection{Frank Fetter - a precursor of praxeology?}

Frank Fetter is commonly seen as the first economist to have integrated interest theory into a causal-realist conception of economics (ROTHBARD, 1987, p. 645; HERBENER, 2011, p. 12). That is, while the pathbreaking character of Böhm-Bawerk's contribution is generally acknowledged, he is yet, equivocally, held guilty of falling back into a productivity approach to interest theory and of having an aggregate concept of capital (MISES, [1949] 2008, p. 525; REISMAN [1990] 1998, p. 797). Fetter, so the story goes, then took up the useful elements in Böhm-Bawerk's work and formulated a truly subjectivist theory of interest.

The starting point for Fetter's treatment of interest is the observation that whenever goods yield a permanent stream of enjoyments, as, for instance, in the case of land, the exchange value of these goods must necessarily be smaller than the total sum of the rents that can be earned from these goods in the future. This means that the incomes that those goods provide have to be discounted by a certain positive factor in order to be traded. In his own words:

A long series (of contract rents), even a perpetual series, may be exchanged for no more than ten, twenty, or twenty-five annual rents. While therefore the selling value of the good is the sum of the values of the rents, it evidently is that sum discounted. (FETTER, 1905, p. 123)

Furthermore, he directly goes on as follows.

Immediately, when we have reached this point in the reasoning, our proposition must suggest itself as self-evidently true in this form: the value of any good is the sum of the entire series of rents it contains,discounted, at some rate, to their present worth. (FETTER, 1905, p. 123)

According to Fetter, discounting need not only be present when perpetual series of incomes are traded, like in the case of land, but also in the transactions of less permanent titles such as durable goods or, indeed, any type of good. The reason for this, according to Fetter, is that the valuation of goods is generally based on the future rents that they afford (FETTER, 1905, p. 73). However, the rents that he means in this context are not contracted rents, viz. streams of payments, but "economic rents", which he describes as the "felt importance of the usufruct" of goods (FETTER, 1905, p. 56; p. 79). For him, economic rent is thus but one form of subjective value, yet one in which all future incomes have undergone a process of capitalization, that is, have been discounted to their present value.

The various subjective discount factors that the acting individuals apply furthermore provide the scope for interest to emerge. They determine the economic rents that constitute the "marginal pairs" among which the exchange value of durable goods will be fixed (FETTER, 
1905, p.145). And, since those dis-count factors are assumed to be positive, these exchange values are lower than the total income generated from those goods in the future. Hence, by appealing to the metaphor of future goods (FETTER, 1905, p.146), there is a systematic, economywide excess of revenue over costs. In Fetter's system (just as in Böhm's), interest income is simply the flip side of the fact that durable assets are generally traded at a discount. Arbitrage furthermore ensures that interest rates cannot significantly deviate from the discount factors that people generally apply (FETTER, 1905, p.147). Consequently, he concludes that, in the market for relatively safe long-term loans, the going rate of time discount is relatively well captured by the going rate of interest (FETTER, 1905, p.149).

There are, however, several problems with this reasoning. Fetter may be right that the seller of a perpetual stream of income must have "discounted" the future rents by a certain factor; otherwise, he would not be willing to accept an amount lower than those rents - contracted rents - that is. But, for the purchaser of such an asset, no such thing can be concluded, since he does value the rents to be received higher than the money spent. It is thus a non sequitur to assert that the purchasing party in such a transaction also "discounts" future rents. Second, and more importantly, it neither follows from Fetter's observation that discounting takes place when non-perpetual assets are traded. Future incomes are always uncertain, and only if a series of rents is infinite can it be known that the sum of its elements exceeds the monetary amount in question. Therefore, it cannot be inferred from observation that discounting is a general mode of action.

Beyond that, the fundamental problem is that discounting also cannot be motivated by praxeology. One might naturally ask: what is the value of the discount factor that people allegedly apply in their actions? Quite obviously, there is no answer to this question. Fetter (1905, p. 126) even explains that "practical men" are not fully aware of their discounting factor, but are "only dimly conscious of the logical nature of the (capitalization) process". This statement, however, makes capitalization an empty concept. Unknown discounting is just as good as no discounting at all. One might then state just as well, but more appropriately, that people value one thing higher than another and act accordingly. That way, the method by which the value difference is established, and its magnitude, would be left unmentioned. However, the notion of discounting, as becomes clear from the second quote given above, cannot escape a cardinal interpretation. If a stream of incomes is discounted at some rate, then there is a numerical value associated with this process, and it is thus presupposed that human beings are in the position to apply a mathematical operation to a subjective estimate, which is clearly erroneous. The truth is that discount factors can only be defined ex post, i.e., based on observed market value. Fetter, however, explicitly uses an ex ante perspective when he writes that

[t]he surplus yielded by capital above its cost is but the realization of a net income made possible by the discounting of future rents. (FETTER, 1905, p. 148)

This reasoning is circular. He starts from the ex post observation that the trading of perpetuities implicitly defines a discount factor, then projects such discounting on the trading 
on all durable goods, ultimately attributing explanatory power to his own definition. In brief, he treats as cause what is actually an effect, as is characteristic of a psychological theory as his.

In certain ways, it is funny to note that Fetter encounters these inconsistencies because he adopts Böhmian metaphors, many of which he explicitly endeavored to avoid (FETTER, 1977, p. 178). Böhm-Bawerk conceived the interest problem as a phenomenon of exchange between present and future, which requires that individuals compare present and future goods. However, it is one thing to assert that people effectuate such comparisons, as BöhmBawerk does, and another to try to describe comparisons, as Fetter does, since any description of a comparison requires an objective standard of measurement, which neither exists for economic goods, nor subjective utility ${ }^{11}$. The notion of a future good, however, leads Fetter to make both these mistakes. When introducing the concept of time-value, which he uses to describe the trade-off between present and future, he writes:

Time-value is the difference between the values of things at different times. (...) The simplest and clearest case of time-value is the difference noticeable in the same thing at different moments. Is this good worth more now or next week? Shall this apple be eaten now or next winter? These questions can be answered only after comparing the marginal utilities, which differ according to the varying conditions of the two periods. All the other cases of time-value can, by the practical device of substituting other goods of equivalent value, be reduced to the typical case of comparing the same thing at different times. (FETTER, 1977, p. 141)

Thus, Fetter introduces a cardinal concept of utility to compare "same" things at different times, and a cardinal concept of goods to compare different things at different times. Sameness is furthermore defined as equivalence in "size, sort, and quality" (FETTER, 1905, p.141). Only with such commensurability in place does it become possible to apply the discounting method, since mathematical operations can only be effectuated with items of like kind. Yet, this conception of a comparison is inherently contradictory, since no acting individual can separate his decision concerning the equivalence of the two satisfactions from the decision as to which satisfaction he actually prefers, which he must do in acting (PELLENGAHR, 1996, p. $26^{12}$. Thus, Böhm's agio paradigm represents an insurmountable obstacle for Fetter, leading him into error.

Fetter's original intention by framing the problem in this way was to avoid what he himself had identified as a "vicious circle" in Böhm-Bawerk's theory, namely that, in Böhm's system, the interest rate has to be known in order to determine the present value of future goods (FETTER, 1914, p.77; 1977, p. 177). However, this statement, as well as most of the other allegations he brought forward against Böhm-Bawerk, evidences a severe misunderstanding

\footnotetext{
${ }^{11}$ The only entity that can make and effectively makes comparisons of different things with-out defining a unit of measurement is the human mind, but as soon as such comparisons are communicated between different minds an objective standard is needed).

${ }^{12}$ Note that this problem is not alleviated by the fact that present and future goods can be represented by monetary equivalents, as Fetter (1905, p.142) and also Herbener (2011, p.53) believe. According to the subjectivist definition of goods, present money and future money are by all means different goods (MENGER, [1871] 1950). Also, see below).
} 
of Böhm's work, as the latter clarified in his reply (BÖHM-BAWERK, 1959c). Böhm-Bawerk was clearly aware of the difference between value and appraisement, using the discounting examples with given rates of interest (1959b, p. 327) mainly for illustrative purposes, as his remarks on pages 331-332 demonstrate.

Consequently, Fetter's approach, while being innovative, cannot be reconciled with praxeological principles and remains psychological in nature. What separates him from Böhm-Bawerk is simply how psychological reasoning is applied. Whereas Böhm stated that comparisons between present and future goods lead to a discount of the latter, Fetter maintained that the discount resides within the comparison itself. And beyond that, the theories are strikingly similar. In particular, both attempt to explain why the resultant marginal pairs are such that the discount of future goods comes into being, or in other words, why, as a rule, valuation favors the present goods. Fetter treats this aspect in a separate section entitled "The Motive for Paying Interest" (1905), and it is certainly worthwhile to reiterate the arguments he therein presents. First, he holds that the scarcity of present goods relative to future goods affects the time-value that people attribute to those goods. Such a relatively high valuation of present goods may, according to Fetter, be due to a "sudden stress of misfortune," or it may represent an attempt to "increase the future earning power of the borrower" (p. 136). Second, he declares that consumption goods have greater importance at the moment than future ones to the "untrained minds", for instance, "the child, the spendthrift, (or) the savage" (p. 136). And third, he even explains that "[m]oney is borrowed to invest in business, to get better machinery, or a larger stock", so that the "businessman is at a point where he can satisfy his wants without encroaching on his capital" (p. 137). These statements, however, correspond quite precisely to the three causes Böhm-Bawerk offers. They are, in fact, outright equivalent. Like Pellengahr (1996, p. 35), one must therefore conclude that Fetter did not progress beyond Böhm-Bawerk at all, but that his work must be considered as an instance of regression, since Böhm explained the value difference between products and factors of production on purely psychological grounds, which in fact need not be false. In contrast, Fetter tried to find a logical argument, where indeed no such logical connection is to be found.

\subsection{Ludwig von Mises - an interest theorist?}

Fetter developed what came to be known as the "pure time preference" theory of interest. The term "time preference", as Fetter uses it, describes instances in which a good or service is preferred at one time rather than another (FETTER, 1915, p.235). Such preference, according to Fetter, can result either in providing for the present or the future. That is, in gratifying a desire, a man demonstrates his preference for the present. Conversely, if a man postpones consumption, i.e., saves a good, then he values present gratification less than consuming the same good at a later point, which is also a form of time preference. Fetter is thus not dogmatic concerning the notion of time preference; he uses the concept in a very general sense and understands it literally. Yet, based on the consideration of many instances of time preference, 
he concludes that "the typical or average preference of men is for present goods and uses", compared to future ones (FETTER, 1915, p. 239) ${ }^{13}$.

Clearly, such intertemporal allocation is not a praxeological category, since it describes the balancing of consumption over time, which evidently requires multiple actions. Moreover, the underlying concept of time-value that Fetter uses to motivate the associated choices is not praxeological either. This becomes evident as Fetter considers time preference consisting of many aspects, including hope and risk, urgent need, and physical change of objects, all of which can be offset and averaged against each other, making them cardinal entities (FETTER, 1915, p. 241). One of those aspects, time discount, i.e., the preference for something simply because it is present, is what Fetter called pure time preference (FETTER, 1915, p. 249) ${ }^{14}$. It is for this reason that his theory has obtained its name.

The reason why the "pure" time preference theory has come to be conceived as praxeological, which in light of the above must strike as a little bit odd, lies in the influence of Mises, who changed the rationale behind the concept of (pure) time preference ${ }^{15}$. According to Mises, time preference is a conceptual notion rather than a cardinal magnitude. Mises argues, just like Fetter, that a man demonstrates in acting that he prefers a present satisfaction to having the same satisfaction later ([1949] 2008, p.481) and vice versa in postponing an action (p. 479). In this context, sameness means identity and not equality, since Mises treats goods of like kind and objects in different contexts as different goods (p. 486). That is, Mises defines time preference via the comparison of the consumption of a good today and the counterfactual consumption of that good at some other point in time (MOSS, 1978, p. 161; HÜLSMANN, 2002, p. 82), which makes it a praxeological category, since the fact that the comparison favors the present is an implication of the concept of action. A postponement of an action results in non-action and therefore does not express time preference at all. Consequently, Misesian time preference can only be positive, whereas Fetter's version can be both positive and negative ${ }^{\mathbf{1 6}}$.

Despite this praxeological impulse, it would be false to consider Mises a decided praxeologist on the theory of interest. On occasions, he clearly advocates the categorical concept of time preference, for instance, when he writes that but he is not consistent in using this conception; for example, when he immediately goes on to state that:

[t] he very act of gratifying a desire implies that gratification at the present instant is preferred to that at a later instant [if anyone] were not to prefer satisfaction in a nearer period of the future to that in a remoter period, he would never consume and so satisfy wants. He would always accumulate; he would never consume and enjoy. (MISES [1949] 2008, p. 481)

\footnotetext{
${ }^{13}$ Note that Fetter did not use the term "time preference" at all up until 1915. For example, in his second Principles textbook, it appears as synonymous with time-value (p. 249). Those two concepts are by all means equivalent (FETTER, 1905). Moreover, Fetter never refers to the "average preference" for the present as "time preference", but always carefully calls the average concept the "market-rate of time preference", thus emphasizing that it arises from the interplay of the different time preferences of individuals.

${ }^{14}$ In the entire book, the term "pure" time preference appears only once. On page 250, he calls it "true" time preference instead.

${ }^{15}$ Mises generally refers to this category as "time preference", thus dropping the label "pure".

${ }^{16}$ It is a convention that positive time preference is associated with a preference for the present.
} 
In stating that any such individual would never consume, he extends the logic beyond the logic of one single action and rather insinuates a lasting disposition of mind. There is hence a certain ambiguity in Mises' writings. One notes with Pellengahr (1996, p. 37) that, actually, "it is not at all easy to find out what he means by time preference". Indeed, Mises attempts to explain the categorical necessity of time preference. However, to do so, he uses equilibrium-based reasoning (p. 482) and explicitly denies that the connection could have anything to do with the physiological condition of man and his necessity to survive (p. 483). Both these assertions weaken his case and give his theory an ad hoc character ${ }^{17}$. There is a host of arguments that motivate why man is more concerned about the closer future than the distant future, but none of them allows for the conclusion that present goods are of higher value: present and future goods are different goods and thus incommensurable. Any such value difference thus bears a praxeological inconsistency, as also Herbener (2011, p. 54) points out ${ }^{18}$.

However, the higher value of present goods is crucial to Mises' interest theory. When introducing the notion of originary interest ${ }^{19}$ he even invokes the higher value of present goods as compared to future goods of like kind and quantity (p.521; p.533), thus falling back into Fetter's logic and revoking his own approach. Furthermore, as stated above, the discounting approach, which Mises endorses, can also not be considered truly praxeological as it masks all the entrepreneurial actions in the production sphere. Therefore, the pure time preference theory is not praxeological, and thus unable to explain what it allegedly explains. Mises' theory of interest is actually simply a complete endorsement of Fetter's work. Indeed, he even declares (p.485) that he did not develop a new theory, but rather restated a theory mostly elaborated by Böhm-Bawerk, and then "perfected" by Fetter, Wicksell, and Fisher. Yet, he failed to realize that this theory is incompatible with his own method. The great merit of Mises' treatment lies in clarifying the timeboundness of action and expressing many praxeological consequences thereof (Ch. XVIII), especially concerning the subjective character of the time period of production (p.477; p.485; p.491).

One should also note that Mises' failure to provide a satisfactory theory of interest does not invalidate the main body of his theoretical edifice. Both Reisman ([1990] 1998, p.689) and Hülsmann (2002, p. 84) state that Mises does not explain price differences between products and factors of production, but only relative prices, and both are right. In fact, Mises formulated the first four Chapters of his treatment of catallactics independent of time preference,

\footnotetext{
${ }^{17}$ Mises uses the term "originary interest" in precisely the same sense as Böhm-Bawerk does. The sentence "[o]riginary interest is a category of human action" ([1949] 2008, p. 524) is therefore irritating. He most certainly means that time preference (which manifests itself in the phenomenon of originary interest) is a category of human action.

${ }^{18}$ As indicated above, Herbener (2011, p.53) believes that money is the exception to that rule. He states that exchanges of present money for future money isolate pure time preference because the moment when a unit of money is held does not affect its usefulness, since money is always a means to the same end, namely exchange. This, however, is an unwarranted postulate with absolutely no praxeological foundation. Ends are never identical or of equal value.

${ }^{19}$ This terminology is rather unfortunate since Böhm-Bawerk originally used the term originary interest to describe a spread measured in money terms, i.e., a market fact to be explained, and not a subjective value difference. Hülsmann (p. 87; p. 92), however, has it the other way around. For him, originary interest is a value difference between two types of goods, and he uses this value difference to explain money interest. Thus, he uses the term originary interest in a unique way. This notwithstanding, we will adopt Hülsmann's terminology from now on.
} 
consistently inserting the phrase "due allowance made for time preference" (MISES, [1949]; 2008, p.293, p.326; p.332; p.336; p.380). Everything he says in those chapters refers to relative prices of complementary and substitutional goods irrespective of whether they are consumer or producer goods. Since interest is not a price, but part of a revenue stream, it is neither directly subject to these considerations nor does it impair them. Besides, in contrast to Hayek (1935), Rothbard ([1962], 2009), and Böhm-Bawerk (see above), Mises also does not attempt to connect the prices of consumer and producer goods along the various stages of production via the rate of interest (p. 533), thus maintaining the subjectivity and the forward-looking character of the time period of production and avoiding the problem of imputation. He simply states that the prices of the complementary factors of production fall behind those of consumer goods (p. 521), leaving the exact relationship open. He thus demonstrates a finer understanding of praxeology and catallactics than other authors. Yet, like most other Austrian writers, he entirely overlooks that: not only consumer goods are final products of businesses, but also fixed capital goods.

\section{Hülsmann's theory of interest}

The standoff, into which the pure time preference theory has led, ultimately required a clear new start. One of its most outspoken critics, Guido Hülsmann provided this new start, presenting an alternative theory of interest that builds on praxeological principles. The praxeological core of that theory lies in the insight that, implied in the concept of action, there is a value difference between the means and the end of an action. Hülsmann calls this value difference originary interest and distinguishes it from gain, which refers to the value difference between chosen and unchosen ends (HÜLSMANN, 2002, p. 90) ${ }^{20}$.

By introducing this concept of originary interest, Hülsmann $(2002$, p. 88) breaks with the theory of imputation, according to which the total amount of the means have the same value as the end they are fit to bring about (MISES, [1949] 2008, p. 201). In doing so, he also solves one of the imputation theory's paradoxes, namely that market exchanges are known to be mutually beneficial while at the same time each trading partner supposedly values the good he gives up (the means) equally high as the good he receives (the end) (HÜLSMANN, 2002, p. 91). Hülsmann's approach, in contrast, avoids this ambiguity, since:

man chooses means and ends, and... he uses the chosen means in the pursuit of his chosen ends. ... [I]t follows from this fact that, by their very nature, ends have, in the eyes of the acting person, a higher value than the corresponding means. (HÜLSMANN, 2002, p. 86)

The fact that means are valued lower than ends is thus a corollary of the fact that they are given up in action to attain an end. ${ }^{31}$

Furthermore, this approach leads to a relatively simple explanation of the interest problem. If all acting individuals value the means lower than the ends, this value spread will

\footnotetext{
${ }^{20}$ Note that means and ends are not considered as choice alternatives: means simply go under in action, since every action is exchange (MISES, [1949] 2008, p. 97).
} 
be reflected in market prices. Of course, what qualifies as a means of production is contingent upon the acting entrepreneurs. Some commodities may be used as final goods in some cases, and as intermediate goods in others. But this does not compromise the theory. Those goods and services that turn out to be considered means of production or final goods will be valued and priced accordingly.

For the theory of originary interest, it is crucial that the means are not only valued lower than the ends at the point in time when they are converted into ends, but also when they are purchased. Yet, Hülsmann points out that in a production plan with multiple consecutive actions there is - in expectation - a hierarchical value relationship between the ultimate goal and the means to attain them. For example, "if Jones exchanges eight hours of his labor against seven loaves of bread from Brown, and then exchanges these against one bottle of wine from Smith, the ultimate purpose of his market activities, ... then all intermediate evaluations are made in light of the overarching evaluation of the final good and all exchange ratios (prices) are formed in light of the exchange ratio (price) of the final transaction" (HÜLSMANN, 2002, p. 96). In a monetary economy, an entrepreneur adopts a production plan if the estimated revenue exceeds the expenses for the factors of production. Plans that do not fulfill this requirement simply never see the light of day. Clearly, an uncountable number of plans fail or are intentionally changed, but given the inherent profitability of the capitalist system (REISMAN, [1990] 1998), it is certain that some entrepreneurial plans are successful, and also that aggregate losses cannot outweigh aggregate profits. Therefore, the phenomenon of profit is the observable result of entrepreneurial effort.

It remains to establish, however, that part of this income is actually interest, but this step follows naturally if we consider the interplay of different and competing entrepreneurial plans and pay attention to the fact that all entrepreneurs have their own originary interest. Overall, competition and arbitrage reduce the price spreads of successful business operations. However, there is a limit to how far competitors bid up the prices of the factors of production, and bid down the sales price as they would not let the expected money spread fall below the level corresponding to their originary interest. In any case, this spread will remain positive (HÜLSMANN, 2002, p. 98). In Hülsmann's own words:

Money interest is that component of observable spreads between selling receipts and cost expenditure that cannot be eradicated without entailing personal disadvantages for those who undertake this eradication. (HÜLSMANN, 2002, p. 100)

Therefore, competition does not dissolve the general existence of money spreads but will only alter the projects in which these spreads are earned. In the economic system, a certain spread is thus always preserved, which is the point to be proven. For Mises, the tool to distinguish between entrepreneurial profit and interest is the concept of the evenly rotating economy. In fact, he conceptualizes interest as an equilibrium phenomenon (MISES, [1949] 2008, p. 521). Hülsmann's theory assumes a process view and, as such, represents a causalrealist approach. 


\section{A theory of interest rates}

One important reason why the praxeological method is suited to establish economic theory is that the concept of action allows for an analysis of human endeavors and an understanding of the nature of capital. This field of praxeology, also called the subjectivist theory of capital, while being most clearly elaborated by Ludwig Lachmann and Israel Kirzner, characterizes the entire Austrian tradition. Its central tenet is that the nature of capital can only be understood teleologically; that is, capital cannot be considered a meaningful concept unless an entrepreneur evaluates it. Only by virtue of human interpretation, it obtains a certain meaning. Otherwise, it is just a mesh of physical objects for which no method of intellectual assessment is known to man (KIRZNER, 1966, p. 113; p. 116; MISES, [1949] 2008, p. 92). The functions that human beings ascribe to capital are, however, always bound up in a certain situation. They are different depending on who ascribes them, and also at different points in time. Consequently, the subjectivist approach portrays a highly dynamic image. In this view, the world is populated by countless individuals who are constantly reformulating their unfinished plans, thereby reassigning new functions to the physical objects under their control (MENGER, ([1871] 1950, p. 80), Lachmann (1978) ${ }^{21}$.

Hence, the primordial concept in the subjectivist theory of capital is the concept of a production plan (LACHMANN, 1978, p. 54). A production plan is an intention or a consideration to combine certain production factors to produce a certain product, which is subsequently used as a means to attain other ends. Thus, as here understood, production is not an end in itself, which distinguishes it from consumption. Each production plan has a certain duration, i.e., a time period of production, which, as Mises ([1949] 2008, p. 476) explains, is a category of human action and thus subjectively measured. In the present context, this time period is here marked by the point of investment and that of the final sale.

Since a production plan is composed of human actions, it follows that production plans always include the use of human labor. A production plan without human intervention is not conceivable. Labor is thus the ultimate element in any production process. Furthermore, a production plan is always characterized by specific production coefficients, which is a corollary of the heterogeneity of physical goods (MISES, [1949] 2008, p. 207). A pondering about production that disregards definite proportions in which its factors are put to use is not considered a plan, but only a pre-stage of it (LACHMANN, 1978, p. 35). Besides, the comparison between different production plans, as effectuated by entrepreneurs, is always based on monetary calculation, such as any other action in the market economy (MISES, [1949] 2008 , p. 230). Hence, to decide between different production plans, the production coefficients, the prices of the production factors, and the anticipated price of the final product have to be known (KIRZNER, 1966, p. 113) ${ }^{22}$. Ultimately, an entrepreneur will then choose the plan that

\footnotetext{
${ }^{21}$ The same idea obviously underlies the pure time preference theory of interest. However, contrary to its ambition, this theory only applies to stationary scenarios and is thus explicitly negligent of the heterogeneity of goods (MURPHY, 2003).

${ }^{22}$ To avoid misunderstandings: this does not mean that all entrepreneurs are price takers in the factor markets. Those known prices can result from a negotiation process, but production plans are always made based on where such negotiations
} 
seems most profitable to him, which can be praxeologically explained by the principle of economizing (MISES, [1949] 2008, p. 241).

Evidently, the subjectivist theory of capital is fully compatible with the interest theory presented in the previous section. However, combining the two allows us to incorporate the determining factors of interest rates into the theory.

It will be expedient for our purposes to distinguish between two sorts of capital goods, circulating and fixed capital goods. Following the subjectivist approach, we use a teleological approach to make this distinction. Intermediate goods are thus intentionally transformed in a production process, whereas fixed capital goods are those the planning individual intends to preserve. In other words, fixed capital goods are used to exploit the services they provide, whereas intermediate goods are used for the sake of their physical substance. By implication, fixed capital goods can also be seen as goods designed to replace a certain amount of labor, which distinguishes them from intermediate goods. For example, a carpenter may decide to employ a tool to process wood and therefore dismiss a number of his assistant employees. However, he cannot purchase wood or any other material in order to reduce the labor input. In fact, he would need more workers if he chose to increase the intake of intermediate products.

Now, the main point for the argument is that the production of fixed capital goods, to a certain extent, requires the same input factors as intermediate and consumer goods. Such nonspecific input is most and foremost labor. Strictly speaking, all factors are ex ante nonspecific, and it is only through entrepreneurial action that they assume a specific character (LACHMANN, 1978, p.16/p.53). But labor is clearly the least specific of all. At the same time, as already discussed, the least specific factor is precisely the one used in every production process and, hence, the price of that factor, as determined within the confines of arbitrage possibilities, assumes economy-wide relevance. Mises puts it as follows:

The fact that one factor, labor, is on the one hand required for every kind of production and on the other hand is, within the limits defined, nonspecific, brings about the general connexity of all human activities. ([MISES, 1949] 2008, p. 389)

Yet, and this is the key point, the quantity of labor needed to produce a fixed capital good is generally smaller than the quantity of labor the capital good is designed to replace. For otherwise, it would just not be capital. For example, as long as the carpenter mentioned above acts under the profit motive, he will only build a machine that helps him carry out a certain task if building it is not an even more time-consuming task in the first place ${ }^{23}$.The same applies to the division of labor and monetary exchange. Fixed capital goods offer ways to save labor input and thus offer cost advantages regardless of who produces them. The source

currently stand.

${ }^{23}$ The exact same reasoning applies to factor combinations, i.e., to cases in which a fixed capital good and certain supporting materials replace some amount of labor and a number of associated capital goods. In fact, this more general case is the regular one. For simplicity and in the quest for essentialism, we will focus on the isolated case of labor and one fixed capital good. Of course, if the labor-saving aspect of a fixed capital good is overcompensated by the cost of materials needed in production, then the good in question ceases to be a fixed-capital good. 
of these cost advantages lies in the fact that the labor required to build a fixed capital good is generally lower than the labor required to perform a task without the help of fixed capital. The use of fixed capital thus frees up an income stream for capitalists ${ }^{24}$.

Entrepreneurs perceive such cost reduction possibilities and act on them. That means they substitute labor against fixed capital. The rate of substitutability equals the rate of return that can be earned in this investment. By general definition, the marginal rate of substitution (MRS) is the rate at which one factor must decrease so that the same output level can be maintained when another factor is increased ${ }^{25}$. Again, this concept is only meaningful in the context of a production plan, i.e., in the comparison of different ways to produce a certain end ${ }^{26}$. Moreover, a marginal rate is determined through action, that is, in the exchange of one existing state against another. Hence, the fixed capital here considered is newly created, fixed capital.

For example, suppose the use of a machine in the production plan for a car allows replacing three workers while leaving all other inputs unchanged. In that case, the marginal rate of substitution is three workers per new machine. In nominal terms, the numerator of the MRS shows the saved labor expenses, and the denominator, the necessary investment expenditure ${ }^{27}$. A perceived MRS greater than one thus incentivizes an entrepreneur to make such an investment. In fact, it will even create a willingness to pay interest to someone who provides the necessary financial means for it. Moreover, in a progressing economy, such marginal decisions are taken over and over again. It is in this sense that the income streams associated with fixed capital investment cannot vanish. Whenever an investment project is completed, new complementarities arise, new business plans may become viable, and new cost reduction possibilities can be concretized.

All this has to be understood in context. Just as the production plan of an entrepreneur depends on the circumstances, so does the marginal rate of substitution. A newly constructed road, for instance, may affect the substitutabilities of many production factors hitherto employed. Also, if some producers change their ideas about the quantity or the quality of their products, then entire production arrangements need to be re-evaluated, and new complementarities and substitutabilities arise. In fact, in the real world, the producers will find themselves in a constant process of revision so that all these substitutive relations have a temporary, if not imaginary, character. However, this does not affect the arguments in the slightest. Complementarities and substitutabilities are of utmost importance to planning entrepreneurs. It is precisely in terms of such relations that entrepreneurs calculate, and they are thus sufficiently real to enter a catallactic theory. Also, the subjective character of originary interest does not undermine the relevance of such relations. To define the MRS via the comparison of different ways to

\footnotetext{
${ }^{24}$ Cost reduction possibilities certainly include risk reduction of any type, but in this context, it is nothing but labor avoidance, e.g., avoiding manufacturing errors and monitoring. Also, the fact that the labor services of different individuals are heterogeneous is here encompassed, since it is appraised factors that are compared and not factors as such.

${ }^{25}$ In neoclassical economics, this concept is mainly referred to as the marginal rate of technical substitution. In this essay, we drop the predicate 'technical', since substitution and substitutability, by Austrian understanding, are not technical questions.

${ }^{26}$ See Equation (3) in the Appendix.

${ }^{27}$ See Equation (6) in the Appendix.
} 
generate a certain end means to assume that the entrepreneurial interest in the completion of the project is independent of how the result is achieved. Originary interest, so to say, cancels out. Finally, the fact that fixed capital goods are durable also does not pose a problem to these concepts, since producers are generally in the position to resell. If the lifespan of a certain tool exceeds the planning period, calculations can be made using expected depreciation costs instead of actual expenses.

We are now in a position to integrate all these aspects. We have seen that all production plans are made conditional on the envisaged output price and the known prices of input factors. Furthermore, fixed capital goods are designed to replace a certain amount of labor, but their production requires less of the nonspecific input they are designed to replace. Consequently, there is always a spread between the cost of production of a fixed capital good and the amount that can be saved through its usage. This excess occurs repeatedly and always finds a manifestation in the cost structure of an economy. It cannot be competed away and is thus interest.

Three cases can be distinguished. If, as a result of competition, the profit margins of fixed capital producers are narrowed down to their originary interest requirements, and a company finances a fixed capital good internally, thus replacing some labor, then it will produce its products at a lower cost as compared to the less capital-intensive mode of production. Its sales price, however, remains unaffected. There is no way this spread can be competed away, since it is embodied in the capital structure. An interest spread thus accrues to the owners of that company as part of their net proceeds (case 1). If this same fixed capital good is financed externally, then the interest margin is split between the debtor and the creditor. That is, part of the interest spread that was otherwise secured by the investor now accrues to the owners of liquid funds who are willing to lend (case 2). Under conditions where loanable funds are scarce, it may well occur that the creditors capture the entire interest margin that arises through the use of the fixed capital. But, in general, it is the result of a negotiation process (REISMAN, [1990] 1998, p.186; p. 720). In both cases, the interest income over and above the originary interest of the parties involved is given by the spread between the saved labor costs and the costs of the capital good: the interest rate corresponds to the MRS between them ${ }^{28}$. Finally (case 3), it is also possible that the cost reduction benefit accrues to the owners of the firms producing fixed capital goods. However, this case is largely hypothetical, and the associated income qualifies as monopoly gain than as interest. It will occur if the supply of fixed capital goods is somehow naturally limited, so that these can be sold above the sum of their cost of production and the originary interest of their producers. In that case, the MRS and the associated income do not correspond to interest income beyond the originary interest of the acting entrepreneurs, but to interest income beyond originary interest and monopoly profit.

${ }^{28}$ See Equations (8) and (9) in the Appendix. 


\section{Discussion}

According to Menger ([1883] 1963, p.44; p.62):

we understand a concrete phenomenon in a theoretical way... by recognizing it to be a special case of a certain regularity (conformity to law)....[T] he nature of this exact orientation of theoretical research... consists in the fact that we reduce human phenomena to their most original and simplest constitutive factors.

The purpose of theory is thus not to account for the whole empirical reality of a phenomenon, but to isolate the forces which bring it about in its purest form. This essay has shown that the determining factor of the rate of interest in an economy is the marginal rate of substitution between labor and fixed capital. Of course, this rate of substitution is not homogeneous in an economy. One could say that it is as heterogeneous as the production plans of entrepreneurs. Nonetheless, this relation exists in each new capital investment, and in their combination, these relations find a reflection in the going rate of interest and the capital yield of a market economy. This is to say that, following Lachmann (1978, p. 74), the phenomenon of interest is here conceived as a result of the operation of market forces, and not as an average of relations as they would exist, side-by-side, in an economy

Of course, the correspondence between interest and newly created fixed capital investment is contingent on the use of such capital. Economies with only consumer and intermediate goods are conceivable, even if counterfactual. However, in such a scenario, interest would emerge from the sets of alternative ends that people pursue and the corresponding willingness to pay, as described by Hülsmann (2002). This means that the theory presented here is fully complementary to that of Hülsmann. The level of interest associated with the marginal rate of substitution of fixed capital is a level over and beyond the level that Hülsmann explains. In a world where investment in fixed capital is absent, Hülsmann's theory fully applies; but as soon as fixed capital investments are introduced, the level of interest is elevated above its original level.

The similarity to Böhm-Bawerk's results is thus striking. Böhm-Bawerk (1930, p. 276) also concluded that the various causes come alternatively into play. In particular, he stated that where the first two are active, the third is suspended, but where the first two are inactive, or not sufficiently active, the third comes into action. Yet, the findings in this paper are not equivalent to those of Böhm-Bawerk, since the MRS and the marginal productivity of capital are simply different relations ${ }^{29}$. Any substitution of capital against labor will, of course, always raise the productivity of a production plan, and the two relations, as instantiated through entrepreneurial actions, are therefore positively correlated. That is, the two concepts co-vary but remain distinct. In addition, while productivity relations may be worth considering $e x$ post, they are not directly related to profitability and an entrepreneur's willingness to pay. They can therefore not be the vantage point of a catallactic theory.

\footnotetext{
${ }^{29}$ In neoclassical economics, this relation is expressed as $f(k)=r$, where $f(k)$ is the derivative of a per-worker production function (BARRO; SALA-MARTIN, 2004, p.32).
} 
Nonetheless, there is a lasting discussion within the Austrian school regarding the influence of productivity on the rate of interest. The root of this discussion lies in BöhmBawerk's results (see Section 2.1). However, antedating Mises' development of praxeology and neglecting some of the Mengerian influence, Böhm-Bawerk assumed a macroeconomic, nonsubjectivist view on capital. This view on capital has become the standard one in the Austrian school (HAYEK 1935; ROTHBARD, [1962] 2009; GARRISON, 2001), lasting disagreement about Böhm's theory of interest determination, notwithstanding. Consequently, it is generally held among Austrian economists and beyond ${ }^{45}$ that there be an equivalence of marginal productivity and interest rates. However, from a subjectivist point of view, this result is false (see above) and meaningless, since marginal adjustments are not defined through actions, but as changes in average productivity (LACHMANN, 1978, p. 80). Furthermore, the central assumption of decreasing returns to capital accumulation is also not tenable. While it may be true that, ceteris paribus, the marginal products of individual factors are declining, this is just not how capital accumulation proceeds. Instead, the insertion of a capital good into a given production plan always changes the complementarities in the surrounding capital structure. Therefore, it is more to the point to characterize capital accumulation by a concomitant change in the composition of capital than by the building up of a stock. Such a process may well be marked by the repeated occurrence of increasing returns (LACHMANN, 1978, p. 37; p. 80; HOLCOMBE, 1998).

Given the questionable premises, it is not surprising that there are many different opinions regarding the relationship between productivity and the rate of interest. The deeper reason for this unclear picture is, however, that none of the underlying theories are praxeological. Moreover, Lachmann, who first championed the praxeological approach to capital theory, left the issue of interest rate determination explicitly unaddressed (LACHMANN, 1978, p. 7; p. 74). To build a praxeological theory means to develop things from the center. No psychological generalizations, no empirical observations, and no assumptions are needed other than there be a world out there to which our reasoning can be applied. Other methods, in contrast, require such assumptions and generalizations, each of which represents a different perspective, so that conflicting views necessarily unfold.

\section{References}

ANTONELLI, E. Le souvenir de Léon Walras et Carl Menger à travers leur correspondence. Economie Appliquée, v. 6, 1953.

BARRO, J. R.; SALA-I-MARTIN, X. Economic Growth. MIT Press, 2004.

BLAUG, M. The formalist revolution of the 1950s. Journal of the History of Economic Thought, v. 25, n. 2, 2003.

BÖHM-BAWERK, E. V. The Positive Theory of Capital. New York: G. E. Stechert and Co., New York, 1930.

BÖHM-BAWERK, E. V. Capital and Interest: A Critical History of Economical Theory. Libertarian Press, South Holland, v. 1, 1959a. 
BÖHM-BAWERK, E. V. Capital and Interest: A Critical History of Economical Theory. Libertarian Press, South Holland, v. 2, 1959b.

BÖHM-BAWERK, E. V. Capital and Interest: A Critical History of Economical Theory. Libertarian Press, South Holland, v. 3, 1959c.

BRAUN, M. Finance behind the veil of money. Liberty.me, 2014.

DE SOTO, J. H. Money, Bank Credit, and Economic Cycles. Auburn: Ludwig von Mises Institute, 2009.

ENDRES, M. The origins of Böhm-Bawerk's greatest error: Theoretical points of separation from Menger. Zeitschrift für die gesamte Staatswissenschaft. Journal of Institutional and Theoretical Economics, p. 143, p. 291-209, 1987.

FETTER, F. A. The principles of economics. The Century Co., New York, 1905.

FETTER, F. A. Interest theories old and new. American Economic Review, v. 4, n. 1, 1914.

FETTER, F. A. Economic principles. The Century Co., New York, 1915.

FETTER, F. A. Capital, Interest, and Rent: Essays in the Theory of Distribution. Kansas City: Sheed Andrew's and McNeel, 1977.

GARRISON, R. Waiting in Vienna. In: Time, Uncertainty, and Disequilibrium, Exploration of Austrian Themes. Lexington, Lexington Books, 1979.

GARRISON, R. Time and Money. The macroeconomics of capital structure. London and New York: Routledge, 2001.

GLORIA-PALERMO, R. The Evolution of Austrian Economics: From Menger to Lachmann. London and New York: Rout-ledge, 1999.

GLORIA-PALERMO, R. In search of the right tool: From formalism to constructivist modelling. GREDEG Working Papers Series, v. 33, 2013.

HAYEK, F. A. Prices and Production. Routledge: London, 1935.

HERBENER, J. M. Introduction. In: The Pure Time-Preference Theory of Interest. Auburn: Ludwig-von-Mises Institute, 2011.

HOLCOMBE, R. G. Entrepreneurship and economic growth. Quarterly Journal of Austrian Economics, v. 1, n. 2, p. 45-62, 1998.

HÜLSMANN, J. G. A theory of interest. Quarterly Journal of Austrian Economics, v. 5, n. 4, 2002.

KALECKI, M. Macrodynamic theory of business cycles. Econometrica, v. 3, p. 327-244, 1935.

KIRZNER I. K. An Essay on Capital. New York: Augustus M. Kelley, 1966.

KIRZNER I. K. The pure time-preference theory of interest: An attempt at clarification. In: J. M. The Pure Time-Preference Theory of Interest. Auburn: Ludwig-von-Mises Institute, [1993] 2011.

LACHMANN, L. M. Capital and its Structure. Kansas City: Sheed Andrew's and McNeel, 1978.

LEWIN, C. Capital in disequilibrium. Auburn: Ludwig von Mises Institute, 2011.

MENGER, C. Grundsätze der Volkswirtschaftslehre. Wien: Wilhelm Braumüller, 1871. 
MENGER, C. Principles of Economics. Glencoe: The Free Press, [1871] 1950.

MENGER, C. Problems of Economics and Sociology. Illinois: Urbana, [1883] 1963.

MENGER, C. Principles of Economics. Auburn: Ludwig von Mises Institute, [1976] 2007.

MISES, L. V. Human Action. Auburn: Ludwig von Mises Institute, [1949] 2008.

MISES, L. V. The theory of money and credit. Auburn: Ludwig von Mises Institute, 1954.

MOSS, L. The emergence of interest in a pure exchange economy: Notes on a theorem attributed to Ludwig von Mises. In: SPADARO, L. M. New Directions in Austrian economics. Kansas City: Sheed Andrews and McNeel, 1978.

MURPHY, R. P. The Austrian subjectivist theory of interest: An investigation into the history of thought. Quarterly Journal of Austrian Economics, v. 4, n. 1, 2001.

MURPHY, R. P. Unanticipated Intertemporal Change in Theories of Interest. New York: New York University, 2003.

PELLENGAHR I. The Austrian subjectivist theory of interest. Frankfurt am Main: Peter Lang, 1996.

REISMAN, G. Capitalism. Laguna Hills: TJS Books, [1990] 1998.

ROBINSON, J. The accumulation of capital. R. D. Irwin, Homewood, 1956.

ROTHBARD, M. N. Man, Economy, and State with Power and Market. Auburn: Ludwig von Mises Institute, [1962] 2009.

ROTHBARD, M. N. Time preference. In: J. EATWELL et al (eds). The new Palgrave. A Dictionary of Economics. Macmillan, London, 1987.

SCUMPETER, J. A. History of Economic Analysis. Oxford University Press, New York, 1954.

WOODS JR, E. T. Why the greenbackers are wrong. Mises Daily Article. Available at: http://mises.org/daily/6391/ Why-the-Greenbackers-Are-Wrong. Acessed: Mar 292013.

ReCeived: September 142021.

APPROVED: SEPTEMBER 242021. 


\section{Appendix}

\section{A Mathematical formulation}

The argument presented in this paper can also be formulated in mathematical language. Such a formulation should, however, not be misinterpreted as equilibrium reasoning. Lewin (2011, p. 15) lists the possible notions of equilibrium that have been proclaimed in the literature. He names, among others, balance of forces, stationarity, plan consistency, optimality. None of them is used here. Moreover, it is clear that this mathematical way of presenting the argument does not add anything to the theory, but only makes it accessible (MISES, [1949] 2008, p. 330).

From the perspective of a capitalist, interest income $I$ is the difference between some amount $M 1$ invested at some point, and the amount $M 2$ received at a later point in time. One may therefore write:

$$
I=M 2-M 1
$$

The rate of interest $r$ is the rate of return that is thereby implied:

$$
r=\frac{M_{2}-M_{1}}{M_{1}}
$$

Furthermore, let be two production plans for the same product $Y$. The letters here denote units of goods of the respective types. Thus, $Y$ can be produced using some factor combination $X$ and, either the amount of labor $L 0+L 1$, or a fixed capital good plus a smaller amount of labor $L 0+K$.

$$
\begin{aligned}
& X+L 0+L 1 \rightarrow Y \\
& X+L 0+K \rightarrow Y
\end{aligned}
$$

We note, furthermore, that to some extent, $K$ must have been produced with the help of labor, however with fewer units, which follows from the definition that fixed capital goods are labor-saving devices. Thus,

$$
\ldots+L 2 \rightarrow K \text { with } L 2<L 1
$$

The prices of all production factors, as well as the sales price of the product, are known to the planning entrepreneur, the former as data, the latter in expectations $\left(\left(\hat{p}_{Y}\right)\right)$. In nominal terms, the production plans can thus be written as

$$
\begin{aligned}
& p_{X} \cdot X+p_{L} \cdot L_{0}+p_{L} \cdot L_{1}<\hat{p}_{Y} \cdot Y \\
& p_{X} \cdot X+p_{L} \cdot L_{0}+p_{K} \cdot K<\hat{p}_{Y} \cdot Y,
\end{aligned}
$$


Where the inequality signs are the manifestation of Hülsmann-type originary interest. The corresponding marginal rate of substitution is thus

$$
M R S=\frac{p_{L} \cdot L_{1}}{p_{K} \cdot K}
$$

For expository purposes, we can also spell out the marginal productivity of such an investment:

$$
M P C=\frac{\hat{p}_{Y} \cdot Y}{L_{0}}-\frac{\hat{p}_{Y} \cdot Y}{L_{1}+L_{0}}
$$

Now assume that Equation (5a) characterizes the status quo. For an entrepreneur to make a fixed capital investment, the associated expenditure must be smaller than the saved labor costs, i.e. $M R S>1$. The factor costs in the production of $K$ are $p_{L} \cdot L_{2}$ plus potentially other input costs. These total costs are lower than $p_{L} \cdot L_{1}$ so long as the other input costs are not prohibitive, i.e., as long as it remains economical to use $K$. The cost reduction thus attained cannot find an outlet other than to become the interest income of someone. Consequently, there is some margin to be earned by some capitalist. Under regular competitive conditions $p_{K}$ will be equal to unit costs plus the originary interest of its producers. Interest income over and above the originary interest of the parties involved is therefore

$$
p_{L} \cdot L_{1}-p_{K} \cdot K=I
$$

Using Equation (1) and taking $p_{K} \cdot K$ as the upfront investment $M_{1}$ we have

$$
M R S=1+r
$$

The interest rate to be earned in this investment thus equals the marginal rate of substitution. In the case of $100 \%$ external financing and extreme scarcity of credit, this rate may be earned on money loans. Otherwise, part of it becomes a component of gross profit in the production of $Y$. 